\title{
The heat of combustion of the urine of sheep and cattle in relation to its chemical composition and to diet
}

\author{
BY K. L. BLAXTER*, J. L. CLAPPERTON AND A. K. MARTIN \\ Hannah Dairy Research Institute, Ayr
}

(Received 1o September 1965-Accepted 30 December 1965)

\begin{abstract}
I. The results of over 500 determinations of the heat of combustion of the urine produced by cattle and sheep have been analysed statistically. 2. The analytical errors for nitrogen, carbon and heat of combustion were $\pm 0.54, \pm \mathrm{r} \cdot 4$ and $\pm 2.2 \%$. The error attached to an estimate of the heat of combustion of the urine produced by an individual sheep in 4 days was $\pm 10 \% \cdot 3$. At the maintenance level of feeding, the heat of combustion of the urine ( $U$ kcal/ $100 \mathrm{kcal}$ food) was related to the crude protein content of the diet $(P \%)$ by the equation

$$
U=0.25 P+\mathrm{r} \cdot 6 \text {, }
$$

with a residual standard deviation of $\pm 0.88 \mathrm{kcal} / \mathrm{I} 00 \mathrm{kcal} .4$. Regression analysis of the relation between the heat of combustion of urine and its $\mathrm{N}$ content showed significant differences with diet. The heat of combustion of the urine of sheep was $9.7 \mathrm{kcal} / \mathrm{g} \mathrm{C}$ and of cattle 10.3 $\mathrm{kcal} / \mathrm{g} \mathrm{C}$, and did not vary with diet. 5. It is shown that the variation in the heat of combustion of urine/g N and its relative constancy/g $\mathrm{C}$ arises largely from variation, from diet to diet, in the proportion of the $\mathrm{N}$ excreted as hippurate. 6 . The results have been combined with the results of a similar analysis (Blaxter \& Clapperton, 1965) of methane production by sheep to show that the ratio of metabolizable energy to digested energy varies very little from mean values of 0.82 for roughages, 0.85 for cereals and 0.79 for oilseed cakes and meals.
\end{abstract}

The metabolizable energy of a feed is its heat of combustion less the heat of combustion of the faeces, urine and combustible gas produced when it is eaten. In many trials with ruminants designed to provide an estimate of the nutritive value of feeds, the measurements made are limited to determinations of the heat of combustion of the feed and the faeces and neither methane nor urine energy are determined. In some trials, however, the nitrogen content of the urine is determined. Methods are available which enable the methane produced when different diets are given to ruminants in different amounts to be predicted with reasonable precision from knowledge of the faecal loss of energy (Blaxter \& Clapperton, 1965) and, if methods were available for estimating the loss of urine energy from commonly measured attributes of the feed, then metabolizable energy could be estimated from the results of trials more simple than complete calorimetric ones.

Understandably many attempts have been made to estimate the heat of combustion of ruminant urine from its more easily measured $\mathrm{N}$ content. The earliest of these consisted of assigning a constant calorific value to the urine/g $\mathrm{N}$ although most of the workers concerned realized that this ratio varied with diet (see Armsby, 1908). More recently the heat of combustion of urine has been related to its $\mathrm{N}$ content by linear regression methods, which, since they rarely have intercepts of zero, implies that the heat of combustion of urine changes with its $\mathrm{N}$ content. Thus Paladines, Reid, Van Niekerk \& Bensadoun (I964) working with sheep found, using three diets, that the

* Present address: The Rowett Research Institute, Bucksburn, Aberdeen. 
heat of combustion of urine $(H, \mathrm{kcal} / \mathrm{day})$ was related to the $\mathrm{N}$ content of the urine, $(N \mathrm{~g} /$ day) by the equation

$$
H=33 \cdot \mathrm{I}+\mathrm{I} 5 \cdot 3 \mathrm{~N}
$$

which indicates that the heat of combustion of the urine/g $\mathrm{N}$ falls as the $\mathrm{N}$ excretion/ day increases. Nehring, Hoffmann, Schiemann \& Jentsch (1963) in a similar study with sheep given cereal and oilseed meals obtained the equation

$$
H=\mathrm{I} 2 \cdot 8+8 \cdot \circ N
$$

This equation predicts the heat of production of the urine to be about half that predicted by the equation of Paladines et al. (1964).

Other less satisfactory approaches have been made. Thus both Elliot \& Loosli (1959) with cattle and Street, Butcher \& Harris (1964) with sheep and cattle have related the heat of combustion of urine/unit weight to its $\mathrm{N}$ content/unit weight. Both found positive intercepts for their regressions. This approach implies that the heat of combustion of the urine produced by an animal in a day is greater when it is simultaneously excreting much water than when it is excreting little, even though the daily $\mathrm{N}$ excretion is unchanged. This assumption does not seem warranted.

This paper is concerned with an analysis of data on the energy, $\mathrm{N}$ and carbon contents of the urine of sheep and cattle collected incidental to calorimetric experiments.

\section{EXPERIMENTAL}

Animals. Wether sheep and steers were used as experimental animals.

Experiments analysed. The experiments analysed were those listed in Table I of Blaxter \& Clapperton ( 1965 ). The total number of determinations of urine composition, each involving a collection of urine for $3-6$ days, exceeded 500 .

Methods. Urine was collected by the aspiration method of Wainman \& Paterson ( $\mathrm{I}^{6}{ }_{3}$ ). A preservative solution $\left(8 \cdot 75 \%, \mathrm{w} / \mathrm{v}, \mathrm{K}_{2} \mathrm{Cr}_{2} \mathrm{O}_{7}\right.$ and $\mathrm{I} \cdot 25 \%, \mathrm{w} / \mathrm{v}, \mathrm{HgCl}_{2}$ ) was added to the urine receptacle before collection; with sheep ro $\mathrm{ml}$ were used for each receptacle and with cattle $100 \mathrm{ml}$. At the end of each day's collection the urine funnel and connecting tubes were rinsed with distilled water and the rinsings added to the urine. A sample of the diluted urine was refrigerated at $+2^{\circ}$ and at the end of the whole period these daily samples were pooled in proportion to the weights of urine produced.

$\mathrm{N}$ was determined by Kjeldahl's method on the fresh urine. For the determination of $\mathrm{C}$ and heat of combustion, the urine was dried under reduced pressure at $+\mathrm{I} 5^{\circ}$. Weighed cellulose blocks were used as primers in the determinations of heat of combustion with an oxygen bomb calorimeter. After 1958 a bomb calorimeter with adiabatic features was used. $\mathrm{C}$ was determined by weighing the $\mathrm{CO}_{2}$ produced after combustion of the sample in a stream of oxygen. All analyses for $\mathrm{C}$ and $\mathrm{N}$ were made in triplicate and those for heat of combustion were made in duplicate. 


\section{RESULTS}

Analytical and collection errors. Graham, Blaxter \& Armstrong (1958), summarizing the results of experiments made in this laboratory up to 1957 , showed that the analytical errors attached to determinations of $\mathrm{N}, \mathrm{C}$ and energy in urine, expressed as coefficients of variation, were for the concentrated urines produced by normal sheep $\pm \mathrm{I} \cdot 3 \%$ for $\mathrm{N}, \pm 5.3 \%$ for $\mathrm{C}$ and $\pm 4.4 \%$ for heat of combustion. For the very dilute urines produced when sheep with fistulas of the rumen were infused with aqueous solutions, the errors were higher. Analysis of the results of sixty-eight analyses of urine from intact sheep made in duplicate or triplicate in $1964-5$ showed analytical errors to be smaller than in 1957. Expressed as coefficients of variation, errors were $\pm 0.54 \%$ for $\mathrm{N}, \pm \mathrm{r} \cdot 4 \%$ for $\mathrm{C}$ and $\pm \mathbf{2 . 2} \%$ for heat of combustion. This improvement probably arose from the careful standardization of methods for $\mathrm{N}$ and $\mathrm{C}$ and the use of an adiabatic bomb calorimeter. Since analyses were always made in duplicate or triplicate the errors attached to mean determinations were less than these coefficients of variations which applied to single analyses.

Variation in the heat of combustion of the urine produced on constant diets. Table I summarizes the results of determinations of the heat of combustion of the urine produced by a series of sheep given the same diet on two or more occasions usually separated by an interval of more than 5 weeks during which interval some other diet had been given. These permit estimation of the errors attached to determinations of the mean heat of combustion of the urine produced by an individual sheep and also the extent of variation in the heat of combustion of the urine produced by different sheep given the same diet in the same amounts.

As the length of period during which the urine was collected increased, so the variation attached to its mean daily heat of combustion for an individual sheep declined while the components of variation associated with differences from sheep to sheep remained fairly constant. Since in all but one of the experiments analysed below the length of collection period was 4 days or more, the error attached to an estimate of the mean daily loss of energy in urine can be taken to be somewhat less than $\pm 10 \%$. This is considerably greater than the analytical error.

Variation in urine energy with diet. The values for energy excreted in the urine when forty-three different diets were given to sheep were analysed. With each diet, urine energy as a percentage of dietary energy was determined when two or more amounts of food were given to two or more sheep. The results of these experiments permitted estimation of the heat of combustion of the urine produced when an animal received an amount of food which resulted in neither gain nor loss of energy to the body, that is at the maintenance level of feeding. They also enabled the change in the heat of combustion of the urine on increasing food intake by multiples of this amount to be estimated.

At the maintenance level of feeding, the heat of combustion of the urine varied from $2.6 \mathrm{kcal} / \mathrm{I} 00 \mathrm{kcal}$ feed for a diet of poor hay and oats to $10.6 \mathrm{kcal} / \mathrm{I} 00 \mathrm{kcal}$ for the same diet supplemented with groundnut meal. The mean excretion for all forty-three diets was $5 \cdot \mathrm{I} \pm \mathrm{r} \cdot 9 \mathrm{kcal} / \mathrm{roo} \mathrm{kcal}$ feed. 
The apparent digestibility of the food was determined in the same experiments, and regression analysis showed that there was no relationship between the apparent digestibility of the energy of the diets and the loss of energy in the urine.

Table I. Variation in the mean heat of combustion of the urine of sheep

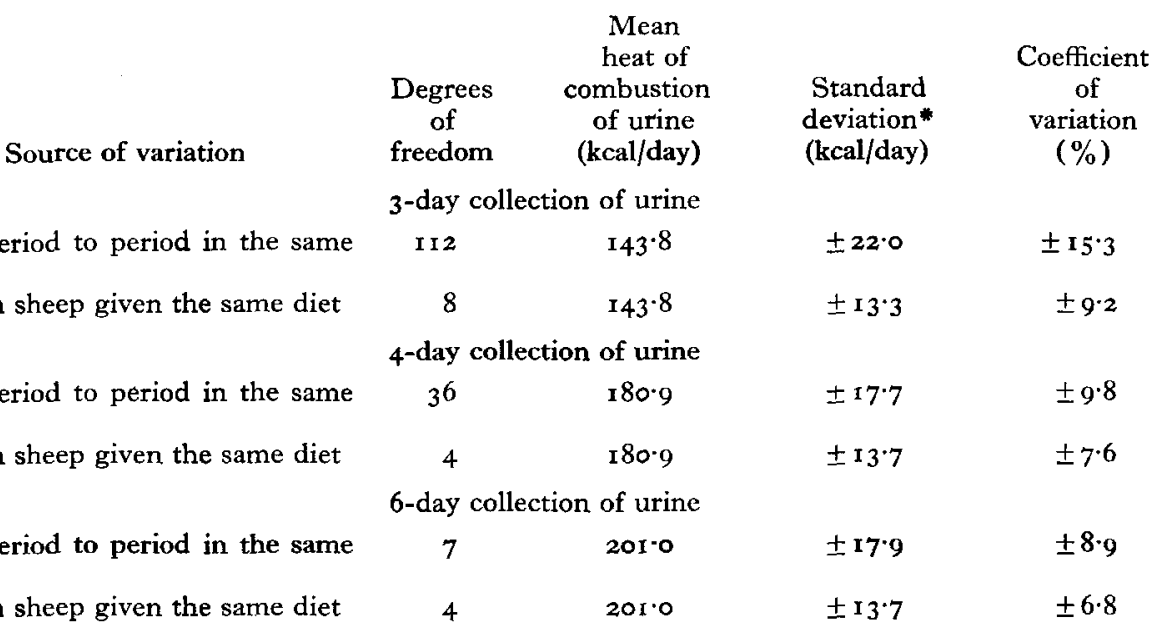

* Derived from the variance components in the analyses of variance.

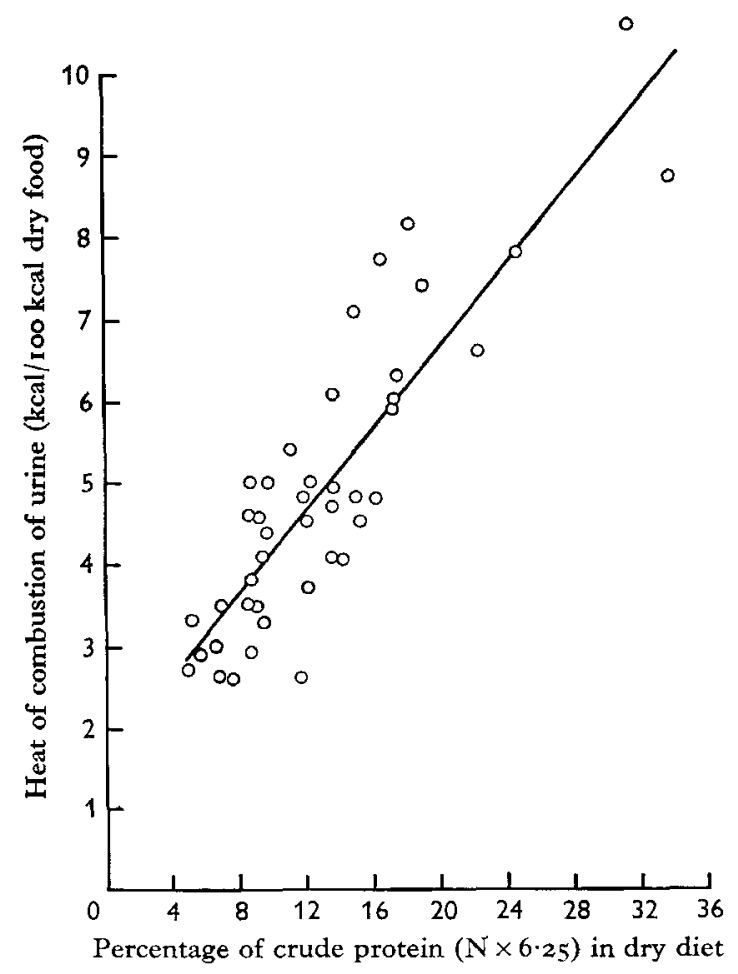

Fig. I. Relation in sheep at the maintenance level of nutrition between the heat of combustion of the urine $/ 100 \mathrm{kcal}$ food and the protein content of the food. 
Vol. 20
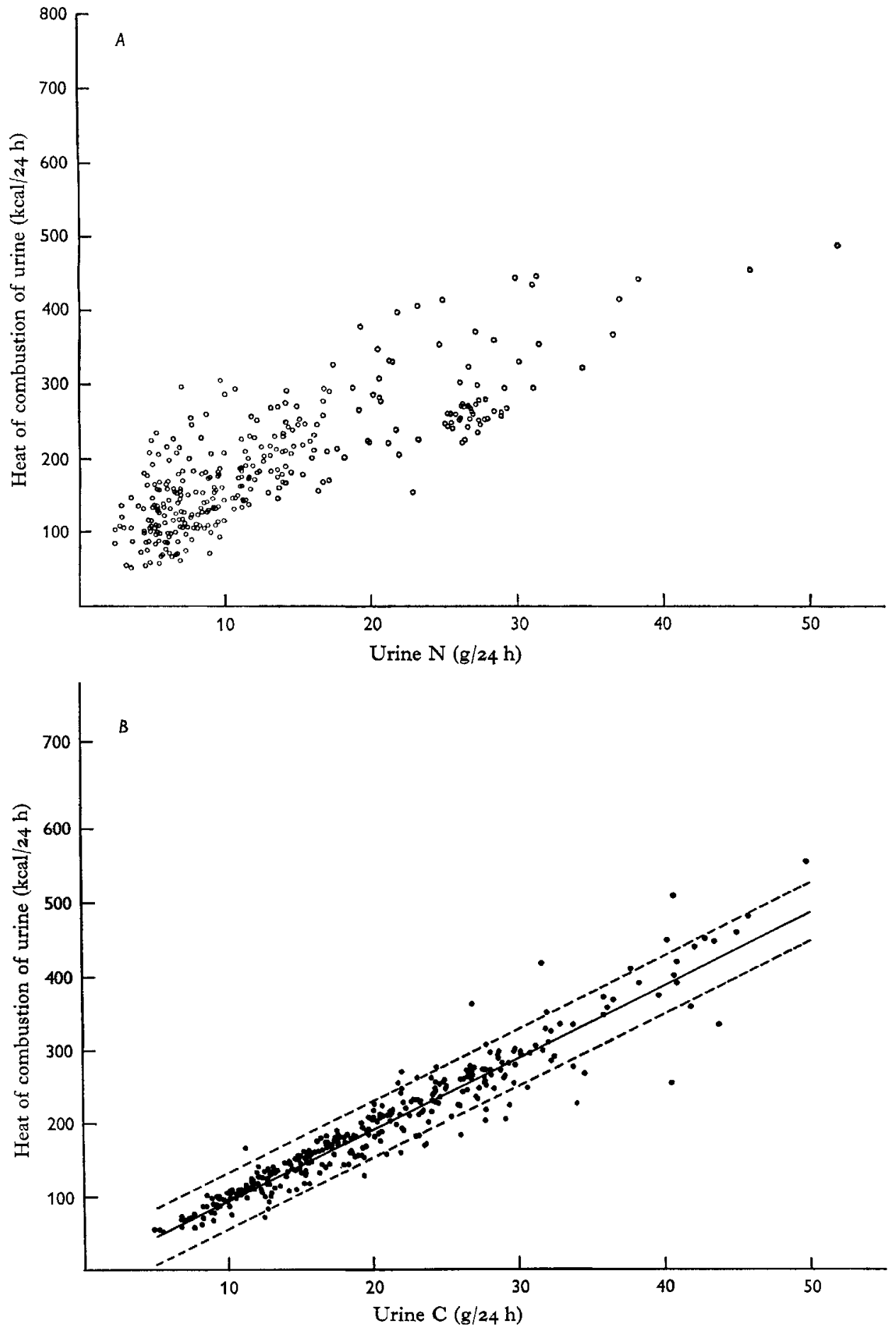

Fig. 2. Relation between the heat of combustion of the urine of sheep and its composition. $(A)$ Heat of combustion of urine as related to the $\mathbf{N}$ content of the urine. $(B)$ Heat of combustion of urine as related to the carbon content of the urine; the solid line is the mean regression and the dotted lines indicate one standard deviation from the regression. 
Table 2. Regressions of heat of combustion of sheep urine on its nitrogen or carbon content

\begin{tabular}{|c|c|c|c|c|c|}
\hline Food & $\begin{array}{l}\text { No. of } \\
\text { deter- } \\
\text { minations }\end{array}$ & $\begin{array}{c}\text { Mean } \\
\text { heat } \\
\text { of } \\
\text { combustion } \\
\text { of urine } \\
\text { (kcal/day) }\end{array}$ & $\begin{array}{l}\text { Regression of heat of } \\
\text { combustion of urine } \\
(H, \mathrm{kcal} / \mathrm{day}) \text { on its } \\
\mathrm{N}(N, \mathrm{~g} / \text { day }) \\
\text { or } \mathrm{C}(C, \mathrm{~g} / \mathrm{day}) \\
\text { content }\end{array}$ & $\begin{array}{l}\text { Statistical } \\
\text { significance } \\
\text { of } \\
\text { regression }\end{array}$ & $\begin{array}{l}\text { Residual } \\
\text { standard } \\
\text { deviation } \\
\text { (kcal/day) }\end{array}$ \\
\hline Fescue hays & 12 & 142 & $\begin{array}{l}H=22 \cdot 1 N+55 \\
H=10 \cdot 3 C-6\end{array}$ & **** & $\begin{array}{r} \pm 27 \cdot 0 \\
\pm 9 \cdot 2\end{array}$ \\
\hline Silages & 47 & 171 & $\begin{array}{l}H=\mathrm{I} \cdot \mathrm{I}+\mathrm{I} 60 \\
H=8 \cdot 5 C+5\end{array}$ & $\begin{array}{l}\text { NS } \\
* * *\end{array}$ & $\begin{array}{l} \pm 48 \cdot 6 \\
\pm 19 \cdot 5\end{array}$ \\
\hline Fresh grasses & 16 & 230 & $\begin{aligned} H & =9 \cdot 8 N+43 \\
H & =8 \cdot 1 C-10\end{aligned}$ & **** & $\begin{array}{l} \pm 23 \cdot 9 \\
\pm 31 \cdot 0\end{array}$ \\
\hline Dried grasses & 12 & 249 & $\begin{array}{l}H=7 \cdot 5 N-113 \\
H=8 \cdot 3 C+25\end{array}$ & *** & $\begin{array}{r} \pm 36 \cdot 8 \\
\pm 6.5\end{array}$ \\
\hline Sugar-beet pulp & I I & 87 & $\begin{array}{l}H=12 \cdot 6 N-44 \\
H=6 \cdot 3 C+22\end{array}$ & **** & $\begin{array}{l} \pm 13 \cdot 4 \\
\pm 1 r \cdot 8\end{array}$ \\
\hline Lucerne & 9 & 288 & $\begin{array}{l}H=10.5 N+9 \\
H=9.6 C+14\end{array}$ & $\begin{array}{l}* * * \\
* * *\end{array}$ & $\begin{array}{r} \pm 2 \mathrm{I} \cdot 4 \\
\pm 9 \cdot 3\end{array}$ \\
\hline Hay and oats $\dagger$ & 6 & 113 & $\begin{array}{l}H=\mathbf{1 2} \cdot 4 N \pm 0 \\
H=10.7 C-\mathbf{I}\end{array}$ & **** & $\begin{array}{l} \pm 9 \cdot 5 \\
\pm 3 \cdot 7\end{array}$ \\
\hline $\begin{array}{l}\text { Hay and oats } \dagger \text { and } \\
\text { decorticated ground- } \\
\text { nut meal }\end{array}$ & 6 & 383 & $\begin{array}{l}H=8 \cdot 7 N+26 \\
H=\text { II I } C-7\end{array}$ & $* * *$ & $\begin{array}{l} \pm 19 \cdot 6 \\
\pm 13 \cdot 5\end{array}$ \\
\hline Poor hay & 6 & 130 & $\begin{array}{l}H=2 \mathrm{I} \cdot 4 N-6 \\
H=9 \cdot 7 C-\mathrm{I}\end{array}$ & $\begin{array}{l}\text { NS } \\
* * *\end{array}$ & $\begin{array}{r} \pm 25 \cdot 6 \\
\pm 4 \cdot 3\end{array}$ \\
\hline $\begin{array}{l}\text { Poor hay and decorti- } \\
\text { cated groundnut meal }\end{array}$ & 6 & 394 & $\begin{array}{l}H=8 \cdot 4 N+24 \\
H=1 \mathrm{I} \cdot \mathrm{I} C-8\end{array}$ & **** & $\begin{array}{l} \pm 38 \cdot 9 \\
\pm 37 \cdot 0\end{array}$ \\
\hline Hay and oats $\downarrow$ & I 8 & 147 & $\begin{array}{l}H=30 \cdot 2 N-39 \\
H=10 \cdot 1 C+1\end{array}$ & $\begin{array}{r}* * \\
* * *\end{array}$ & $\begin{array}{r} \pm 32 \cdot 8 \\
\pm 5 \cdot 2\end{array}$ \\
\hline $100 \%$ maize & 6 & 86 & $\begin{array}{l}H=\text { 1 1 } 3 N+18 \\
H=10 \cdot 2 C-9\end{array}$ & NS & $\begin{array}{r} \pm 19 \cdot 8 \\
\pm 7 \cdot 3\end{array}$ \\
\hline $80 \%$ maize, $20 \%$ hay & 6 & 82 & $\begin{array}{l}H=7 \cdot 8 N+42 \\
H=9 \cdot 0 C+I\end{array}$ & NS & $\begin{array}{r} \pm 20.9 \\
\pm 9.0\end{array}$ \\
\hline $60 \%$ maize, $40 \%$ hay & 6 & 99 & $\begin{array}{l}H=-2 \cdot 3 N+1 \text { II } \\
H=9 \cdot 7 C-13\end{array}$ & NS & $\begin{array}{l} \pm 3 I \cdot I \\
\pm 17 \cdot I\end{array}$ \\
\hline $40 \%$ maize, $60 \%$ hay & 6 & 123 & $\begin{array}{l}H=10.4 N+64 \\
H=9.8 C-10\end{array}$ & NS & $\begin{array}{l} \pm 43.9 \\
\pm 18.5\end{array}$ \\
\hline $20 \%$ maize, $80 \%$ hay & 6 & 140 & $\begin{array}{l}H=-9 \cdot 6 N+199 \\
H=8 \cdot 5 C+7\end{array}$ & $\underset{* *}{N S}$ & $\begin{array}{l} \pm 30 \cdot 0 \\
\pm 12 \cdot 3\end{array}$ \\
\hline 100\% hay & 6 & 159 & $\begin{array}{l}H=30 \cdot 2 N-39 \\
H=10.1 C+1\end{array}$ & $\stackrel{* *}{* * *}$ & $\begin{array}{r} \pm 32 \cdot 8 \\
\pm 5 \cdot 2\end{array}$ \\
\hline High-protein cubes & 24 & 256 & $\begin{array}{l}H=6 \cdot 3 N+87 \\
H=7 \cdot 6 C+49\end{array}$ & $* *$ & $\begin{array}{l} \pm 13.7 \\
\pm 10.5\end{array}$ \\
\hline $\begin{array}{r}\text { Dried grasses: young } \\
\text { leafy } \\
\text { late } \\
\text { leafy }\end{array}$ & 12 & 242 & $\begin{array}{l}H=20 \cdot 3 N-49 \\
H=10 \cdot 1 C \pm 0 \\
H=13 \cdot 2 N+46 \\
H=9 \cdot 9 C+3\end{array}$ & $\begin{array}{l}* * * \\
* * * \\
* * * \\
* * *\end{array}$ & $\begin{array}{r} \pm 20.5 \\
\pm 4.8 \\
\pm 46.8 \\
\pm 36.8\end{array}$ \\
\hline Hay: early flowering & 34 & I93 & $\begin{array}{l}H=\mathbf{I} \cdot 9 N+6 \mathbf{I} \\
H=9 \cdot 6 C+4\end{array}$ & $* * *$ & $\begin{array}{l} \pm 48 \cdot 8 \\
\pm 13 \cdot 2\end{array}$ \\
\hline seed setting & 26 & 160 & $\begin{array}{l}H=14.9 N+4 \mathrm{r} \\
H=10.0 C+5\end{array}$ & $\begin{array}{l}* * * \\
* * *\end{array}$ & $\begin{array}{l} \pm 28.7 \\
\pm 16.8\end{array}$ \\
\hline
\end{tabular}

Significant at $0.01<P<0.05$.

* Significant at $0.001<P<0.01$.

NS Not significant.

$+30 \%$ by weight hay, $70 \%$ by weight rolled oats.

$\ddagger 66 \%$ by weight hay, $34 \%$ by weight rolled oats. 
As shown in Fig. I, the heat of combustion of the urine/roo kcal feed, determined at the maintenance level of nutrition, increased with increasing crude protein content of the dry matter of the diet. For the forty-three observations the regression of the heat of combustion of the urine, $U$ (kcal/roo kcal feed) on the protein content of the dry diet, $P(\%)$ was

$$
U=0 \cdot 25 P+\mathrm{I} \cdot 6
$$

with a residual standard deviation of \pm 0.88 which is $\pm 17 \%$ of the mean value. The loss of energy in the urine at the maintenance level expressed per roo kcal food can thus be predicted from the $\mathrm{N}$ content of the food with $95 \%$ confidence limits of \pm 2 kcal.

When the amount of food given was increased above that required for maintenance, the heat of combustion of the urine/roo kcal food decreased in thirty-seven experiments and increased in six experiments. The mean change on doubling food intake was $-0.73 \pm 0.77 \mathrm{kcal} / \mathrm{r} 00 \mathrm{kcal}$ food and there was no relationship between the magnitude of the change and either the apparent digestibility of the food or its crude protein content.

Relation between the heat of combustion of urine and its $C$ and $N$ content during feeding. 'The results of $3 \mathrm{I}_{5}$ individual determinations of the mean daily excretion of $\mathrm{N}, \mathrm{C}$ and energy in the urine of sheep, representing the urine excretion when forty-one different diets were given, were divided into twenty-two groups and analysed statistically. Some groups included results obtained with several foods which were of the same type, thus the observations made with six silages were all included in one group and certain hays and dried grasses were also grouped together. Other groups contained results obtained with single foods or diets. In each group the $\mathrm{N}, \mathrm{C}$ and energy values included determinations made when a number of different amounts of food were given. Within each group the regressions of the heat of combustion of the urine on its $\mathrm{N}$ content and on its $\mathrm{C}$ content were determined with the results shown in Table 2.

Table 2 shows that in the twenty-two groups, with one exception for fresh grasses, the residual standard deviation of the heat of combustion of the urine estimated from an equation based on $\mathrm{N}$ was greater than that for the corresponding equation based on $\mathrm{C}$. The regression coefficients of heat of combustion of urine on its $\mathrm{N}$ content varied from +30.2 to $-9.6 \mathrm{kcal} / \mathrm{g}$, whereas the corresponding regression coefficients for $\mathrm{C}$ varied only from $7 \cdot 6$ to I I. I kcal/g. The intercepts of the equations based on $\mathrm{N}$ also varied considerably compared with those for $C$.

Analysis of covariance of the results showed that there were statistically significant differences $(P<0.001)$ between the twenty-two regressions of the heat of combustion of urine on its $\mathrm{N}$ content. This precludes the possibility of using a single regression equation to predict the heat of combustion of sheep urine from its $\mathrm{N}$ content. Covariance analysis in which the $\mathrm{C}$ content of the urine was the independent variable showed, however, that there were no differences between the twenty-two regression coefficients of heat of combustion of urine on its $\mathrm{C}$ content. The pooled within-group regression of the heat of combustion of sheep urine ( $H \mathrm{kcal} / \mathrm{day})$ on $\mathrm{C}$ content $(C \mathrm{~g} /$ day) was

$$
H=9 \cdot 66 C-3 \cdot 0,
$$


with a residual standard deviation of $\pm 19.5 \mathrm{kcal} /$ day or $\pm 10.1 \%$ of the mean value. The intercept of the equation was not significant statistically, so that no error would accrue if the heat of combustion of the urine was estimated as $9 \cdot 7 \mathrm{kcal} / \mathrm{g} \mathrm{C}$.

A similar analysis was made of fifty-one determinations of the heat of combustion, $\mathrm{N}$ and $\mathrm{C}$ content of cattle urines. These determinations were made when cattle were given the same diets as were sheep, and the regressions given in Table 3 for cattle may be compared directly with those for sheep in Table 2 in lines I I-I 7 inclusive. As with sheep, the residual standard deviation when the heat of combustion of the urine was estimated from its $\mathrm{N}$ content, the range of the regression coefficients of heat of combustion of urine on its $\mathrm{N}$ content and the range of intercepts of the equations relating heat of combustion to $\mathrm{N}$ content were all greater than the corresponding values obtained when the $\mathrm{C}$ content of the urine was the independent variable. Covariance analysis showed the differences between the regressions of the heat of combustion of urine on its $\mathrm{N}$ content to be statistically significant (O. I $>P>0.05)$ which precludes the use of a generalized relationship for predicting the heat of combustion of cattle urine from its $\mathrm{N}$ content. There were no significant differences between the groups with respect to the regression of the heat of combustion ( $H \mathrm{kcal} /$ day) of cattle urine on its $\mathrm{C}$ content ( $\mathrm{Cg} / \mathrm{day})$, the pooled within experiment regression being

$$
H={ }^{0} 0 \cdot 33 C-3^{8},
$$

with a residual standard deviation of $\pm 33 \mathrm{kcal} /$ day which corresponds to $\pm 3.9 \%$

Table 3. Regressions of heat of combustion of cattle urine on its nitrogen or its carbon content

\begin{tabular}{|c|c|c|c|c|c|}
\hline Food & $\begin{array}{c}\text { No. of } \\
\text { deter- } \\
\text { minations }\end{array}$ & $\begin{array}{c}\text { Mean } \\
\text { heat } \\
\text { of } \\
\text { combustion } \\
\text { of urine } \\
\text { (kcal/day) }\end{array}$ & $\begin{array}{c}\text { Regression of heat of } \\
\text { combustion of urine } \\
(H, \mathrm{kcal} / \mathrm{day}) \\
\text { on its } \mathrm{N} \text { content } \\
(N, \mathrm{~g} / \mathrm{day}) \\
\text { or on its } \\
\mathrm{C} \text { content } \\
(C, \mathrm{~g} / \text { day })\end{array}$ & $\begin{array}{c}\text { Statistical } \\
\text { significance } \\
\text { of } \\
\text { regression }\end{array}$ & $\begin{array}{l}\text { Residual } \\
\text { standard } \\
\text { deviation } \\
\text { (kcal/day) }\end{array}$ \\
\hline Hay and oats & I 5 & 956 & $\begin{array}{l}H=34.4 N-217 \\
H=10.5 C-24\end{array}$ & $\begin{array}{l}* * \\
* * *\end{array}$ & $\begin{array}{r} \pm 195.9 \\
\pm 26.5\end{array}$ \\
\hline $\begin{array}{l}95 \% \text { maize } \\
5 \% \text { hay }\end{array}$ & 6 & 534 & $\begin{array}{l}H=9.7 N+137 \\
H=9.3 C+27\end{array}$ & * & $\begin{array}{l} \pm 66.4 \\
\pm 24.9\end{array}$ \\
\hline $\begin{array}{l}80 \% \text { maize } \\
20 \% \text { hay }\end{array}$ & 6 & 544 & $\begin{array}{l}H=6 \cdot 1 N+307 \\
H=9 \cdot 6 C+5\end{array}$ & $\begin{array}{l}\text { NS } \\
*\end{array}$ & $\begin{array}{l} \pm 86.7 \\
\pm 50.0\end{array}$ \\
\hline $\begin{array}{c}60 \% \text { maize } \\
40 \% \text { hay }\end{array}$ & 6 & 653 & $\begin{array}{l}H=7 \cdot 7 N+391 \\
H=11.5 C-13^{\circ}\end{array}$ & $\begin{array}{l}\text { NS } \\
* *\end{array}$ & $\begin{array}{r} \pm 140 \cdot 5 \\
\pm 42 \cdot 8\end{array}$ \\
\hline $\begin{array}{c}40 \% \text { maize } \\
60 \% \text { hay }\end{array}$ & 6 & 817 & $\begin{array}{l}H=\mathrm{I}_{5} \cdot 4 N+243 \\
H=9 \cdot 4 C+25\end{array}$ & * $* *$ & $\begin{array}{r} \pm 128.7 \\
\pm 15.4\end{array}$ \\
\hline $\begin{array}{l}20 \% \text { maize } \\
80 \% \text { hay }\end{array}$ & 6 & $103 \mathrm{r}$ & $\begin{array}{l}H=25.9 N+96 \\
H=10.9 C-103\end{array}$ & *** & $\begin{array}{r} \pm \mathrm{I} 34 \cdot 8 \\
\pm 5 \mathrm{I} \cdot \mathrm{I}\end{array}$ \\
\hline $100 \%$ hay & 6 & $\begin{array}{r}\text { I } 172 \\
\\
* \text { Signific } \\
* * \text { Signific } \\
* * \text { Signific } \\
\text { NS, not sig. }\end{array}$ & $\begin{array}{l}H=6 \mathrm{I} .7 N-1072 \\
H=9.6 C-12 \\
\text { to.01 }<P<0.05 \\
\text { o.00I }<P<0.01 \\
\text { it } P<0.001 \\
\text { int. }\end{array}$ & $\begin{array}{l}* \\
* * *\end{array}$ & $\begin{array}{r} \pm \text { I I } 5.6 \\
\pm 35.4\end{array}$ \\
\hline
\end{tabular}


of the mean heat of combustion. When sheep were given the same diets the mean regression coefficient was $9.9 \pm 0.22 \mathrm{kcal} / \mathrm{g} \mathrm{C}$. This was not statistically significantly different from that for cattle (I0.3 $\pm 0 \cdot 15 \mathrm{kcal} / \mathrm{g} \mathrm{C})$.

Relation between the heat of combustion of urine and its $C$ and $N$ contents during starvation. An analysis of the relationship between the heat of combustion of the urine produced by sheep on the 3 rd, $4^{\text {th }}$ and 5 th days of starvation and its $\mathrm{C}$ and $\mathrm{N}$ content
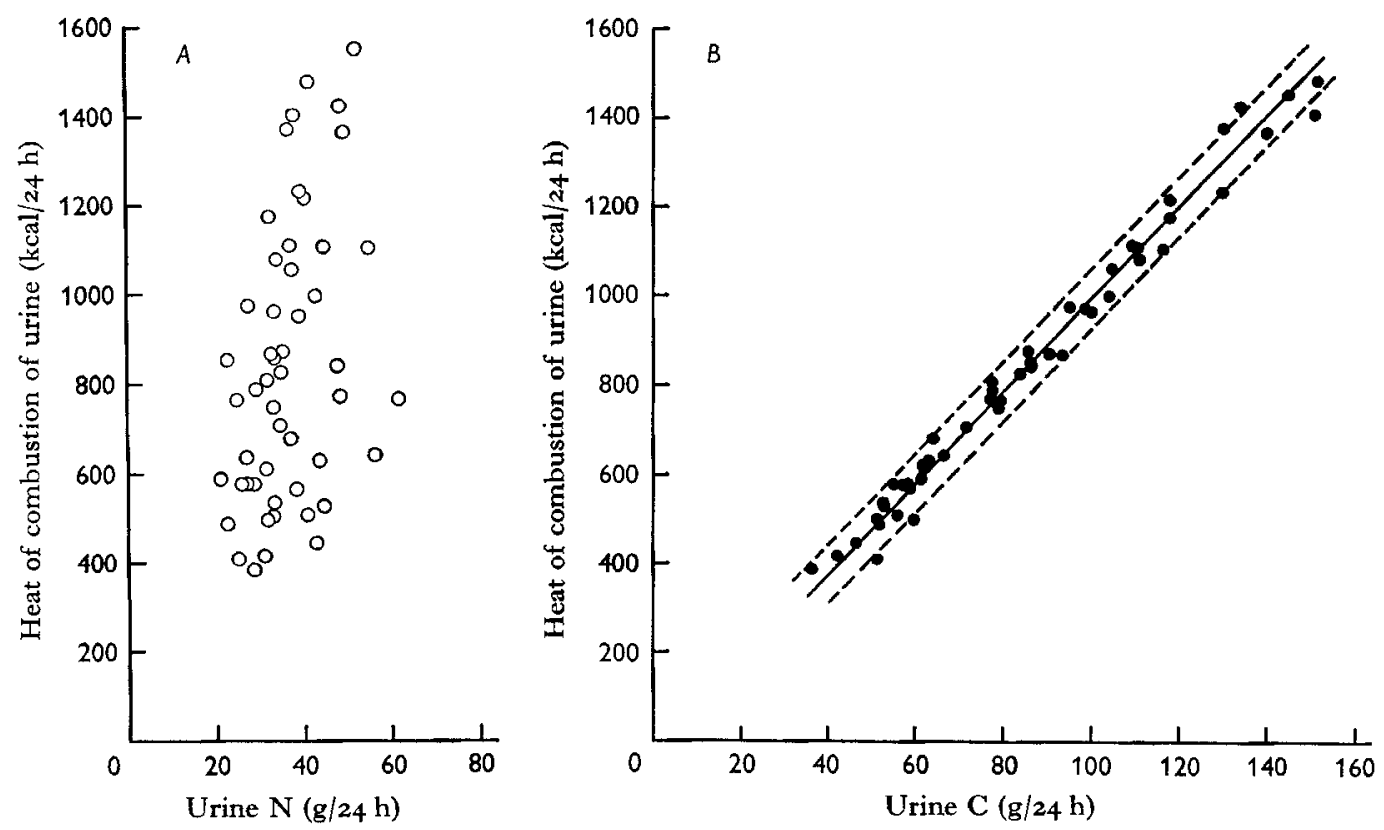

Fig. 3. Relation between the heat of combustion of the urine of cattle and its composition. $(A)$ Heat of combustion of urine as related to the nitrogen content of the urine. $(B)$ Heat of combustion of urine as related to the carbon content of the urine; the solid line is the mean regression and the dotted lines indicate one standard deviation from the regression.

was made with fifty-eight separate samples. The results of one $\mathrm{C}$ analysis were lost. The regression for $\mathrm{N}$ was

$$
H=8.93 N-8,
$$

with a residual standard deviation of $\pm 10 \cdot 0 \mathrm{kcal}$ or $\pm \mathrm{I} 6 . \mathrm{I} \%$ of the mean. For $\mathrm{C}$ the corresponding regression was

$$
H=10 \cdot 04 C-3 \cdot 0,
$$

with a residual standard deviation of $\pm I I \cdot 0 \mathrm{kcal}$ or $\pm 17.5 \%$ of the mean. In this instance the error of prediction of the heat of combustion of the urine from its $\mathrm{N}$ content was slightly less than the error of prediction from its $\mathrm{C}$ content. The intercepts of both the equations were not significantly different from zero. The regression coefficient for $\mathrm{C}$, $10 \cdot 0 \pm 0.6$, was not significantly different from the value when the sheep were given food $(9 \cdot 7 \pm 0 \cdot 2)$.

Chemical composition in relation to the heat of combustion of urine. The relative constancy of the energy value of urine/g $\mathrm{C}$, and the considerable variation with diet 
of the heat of combustion of urine/g $\mathrm{N}$ is clearly related to the variation with diet in the excretion of end-products of $\mathrm{N}$ and carbohydrate metabolism in the urine. The heat of combustion of the major components of urine expressed as $\mathrm{kcal} / \mathrm{g} \mathrm{C}$ are: urea $\mathrm{r} 2 \cdot 6$, creatine $\mathrm{I} \cdot 7$, creatinine $\mathrm{II} \cdot 7$, allantoin $9 \cdot 9$, hippuric acid 9.4 , uric acid $7 \cdot 7$, benzoic acid $9 \cdot 2$, acetone $I I \cdot 9$, and that of most amino acids ranges from $9 \cdot 9$ to $I I \cdot 9$. Carbonate and bicarbonate obviously have values of zero. The coefficients of 9.7 $\mathrm{kcal} / \mathrm{g} \mathrm{C}$ and $10.3 \mathrm{kcal} / \mathrm{g} \mathrm{C}$ found for sheep and cattle urine respectively, which are slightly lower than the above figures, would imply the presence of some carbonate or bicarbonate carbon in the urine.

The heats of combustion of the major components of urine expressed as $\mathrm{kcal} / \mathrm{g} \mathrm{N}$ are: urea 5.4 , ammonia 7.5 , creatine $I_{3} \cdot 3$, creatinine 13.4 , allantoin 7.4 , uric acid 7.2 , hippuric acid $72 \cdot 3$, and an average value for amino acids is $39 \cdot 2$. Considerable variation in the heat of combustion of urine $/ \mathrm{g} \mathrm{N}$ is thus possible when its composition varies, and though the major component responsible is hippuric acid, the excretion of $\mathrm{N}$-free compounds such as glucuronic acids and acetone would clearly increase the heat of combustion/g N. Table 4 shows the results of seven experiments arranged in order of the determined heat of combustion of the urine/g N. Good agreement was found between the observed heat of combustion of the urine and that computed from its analysis for urea, $\mathrm{NH}_{3}$, creatine, creatinine, allantoin and hippurate $\mathrm{N}$.

In this regard the heat of combustion of sheep urine/g $\mathrm{N}$ in the experiments was classified according to the energy retention of the animals producing it. The heat of combustion of urine/g N was significantly greater $(P<0.00 \mathrm{I})$ the higher the energy retention of the sheep, that is the higher their food intake. This largely reflects a dilution, by hippurate derived from food, of the $\mathrm{N}$-containing compounds in the urine, which are excreted in fairly constant amounts irrespective of the amount of food given. It also reflects the fact that, when energy is retained, amino acids are also retained thus reducing the excretion of urea.

\section{DISCUSSION}

The analysis of the relation between the mean heat of combustion of the urine produced each day and its $\mathrm{N}$ content shows that the discrepancy between the regression equations of Paladines et al. (1964) and of Nehring et al. (1963) is understandable. Wide variation in regression equations relating the heat of combustion of urine to its $N$ content can occur, and they largely reflect changes with diet in the proportion of the $\mathrm{N}$ excreted as hippurate. Regressions of the heat of combustion of the urine on the $\mathrm{C}$ content of the urine, however, showed no such variation with diet, and, if it should be necessary to calculate the calorific value of urine from a chemical determination, then a $\mathrm{C}$ determination would suffice. It is, however, simpler to determine the calorific value of the urine directly.

An estimate or a determination of the energy of the organic compounds excreted in the urine each day is necessary if the metabolizable energy of diets is to be computed. The calculations above showed that at the maintenance level of nutrition the heat of combustion of the urine expressed as a percentage of the heat of combustion of the 

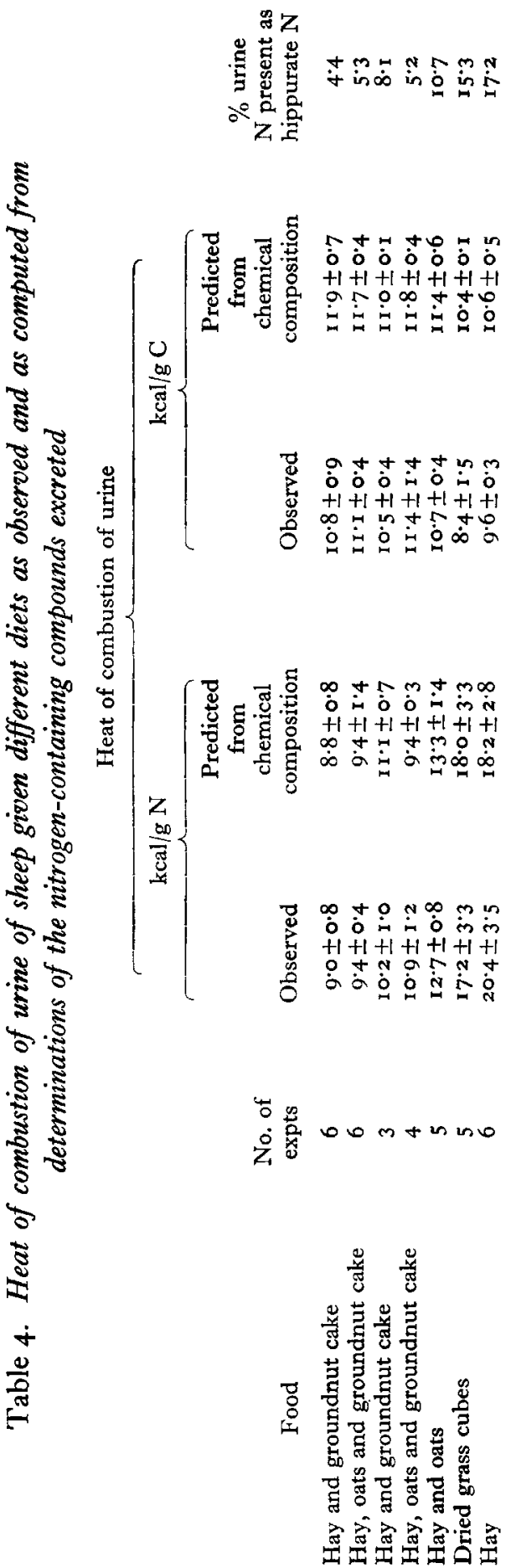
diet can be predicted with $95 \%$ confidence limits of $\pm 2 \%$ by an equation relating it to the crude protein content of the diet. The range of materials tested was sufficiently wide to make the equation of general applicability.

Table 5. Metabolizable energy expressed as a percentage of digested energy for different diets, calculated using the equation of Blaxter $\Xi^{\circ}$ Clapperton ( $\mathrm{I}_{96} 6_{5}$ ) to predict $\mathrm{CH}_{4}$ energy and the equation given in the text for predicting urine energy

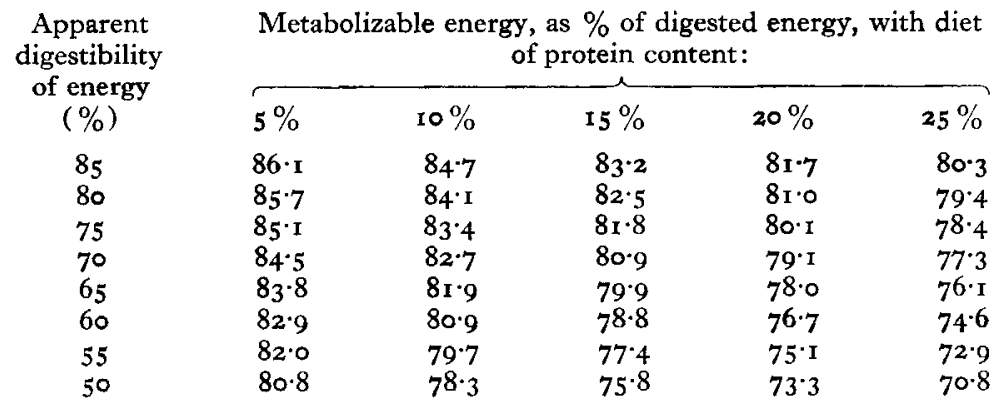

If this equation relating urine energy to protein content of the diet and the equation of Blaxter \& Clapperton (1965) relating methane energy to the apparent digestibility of the energy of the diet are combined, then the metabolizable energy of diets can be predicted from the results of trials in which the apparent digestibility of energy and the $\mathrm{N}$ content of the diet have been the only measurements made. Table 5 summarizes the results of such calculations where they have been expressed in the form $100 x$ metabolizable energy/digested energy. Table 5 suggests that for diets containing roughages, which when of low apparent digestibility contain little protein and when of high digestibility usually contain appreciable amounts, the ratio of metabolizable energy to digested energy departs little from an average value of 0.82 . For cereals, which rarely contain more than $10-15 \%$ crude protein but have high apparent digestibilities, a ratio of 0.85 would be more appropriate and with oilseed cakes and meals, which usually combine a high protein content with a high apparent digestibility, a ratio of 0.79 would be a reasonable one to use. The errors attached to these factors computed from the errors of estimate of the equations concerned are about $\pm \mathrm{r} \cdot 2 \%$ for diets of high apparent digestibility, increasing to $\pm x \cdot 7 \%$ for those with low apparent digestibility.

\section{REFERENCES}

Armsby, H. P. (1908). Principles of Animal Nutrition. New York: John Wiley and Sons.

Blaxter, K. L. \& Clapperton, J. L. (1965). Br. F. Nutr. I9, 5 I I.

Elliott, J. M. \& Loosli, J. K. (1959). F. Dairy Sci. 42, 836 .

Graham, N. McC., Blaxter, K. L. \& Armstrong, D. G. (1958). E.A.A.P. Publs Eur. Ass. Anim. Prod. no. 8, p. 157 .

Nehring, K., Hoffimann, L., Schiemann, R. \& Jentsch. W. (1963). Arch. Tierernähr. 13, I 93.

Paladines, O. L., Reid, J. T., Van Niekerk, B. D. H. \& Bensadoun, A. (I 964). Y. Anim. Sci. $23,528$. Street, J. C., Butcher, J. E. \& Harris, L. E. (1964). F. Anim. Sci. 23, 1039.

Wainman, F. W. \& Paterson, D. (I963). F. agric. Sci., Camb. 6r, 253. 